\title{
Swarm-like seismic activity in 1989, 1990 and 1997 preceding the 2000 Western Tottori Earthquake
}

\author{
Takuo Shibutani ${ }^{1}$, Setsuro Nakao ${ }^{1}$, Ryohei Nishida $^{2}$, Fumiaki Takeuchi $^{1}$, Kunihiko Watanabe $^{1}$, and Yasuhiro Umeda ${ }^{1}$ \\ ${ }^{1}$ Disaster Prevention Research Institute, Kyoto University, Kyoto 611-0011, Japan \\ ${ }^{2}$ Faculty of Civil Engineering, Tottori University, Tottori 680-8552, Japan
}

(Received September 12, 2001; Revised July 1, 2002; Accepted July 3, 2002)

\begin{abstract}
Swarm-like seismic activity including six moderate events $(\mathrm{Mj}=5.1-5.4)$ occurred in 1989,1990 and 1997 in the same area as the 2000 Western Tottori Earthquake $(\mathrm{Mj}=7.3)$. For each time period, we carried out temporary seismic observations in and around the source area and processed the data together with data from permanent stations, to determine the hypocenters precisely. In this study we also redetermined the earthquake locations in each seismic activity using a two-step master event technique with common master events, so that the accuracy in the relative locations of the events was improved. The purpose of this study is to clarify the relationship between the preceding seismic activity and the mainshock in 2000 by comparing the hypocenter distributions. The relocated hypocenter distributions show that the three preceding swarms occurred in different parts of the same fault plane as the 2000 Western Tottori Earthquake. The b-values of the preceding swarms were low (0.51-0.67), suggesting a high stress level in the area. The mainshock initiated in the area of the preceding swarms. The rupture propagated with relatively small slip $(\sim 1 \mathrm{~m})$ in the area for the first three seconds. Then, it developed to main rupture with large slip (2-4 m) outside the area toward the southeast.
\end{abstract}

\section{Introduction}

A large earthquake occurred on 6 October 2000 with the hypocenter in the western part of Tottori Prefecture in the southwestern part of Honshu, Japan. The JMA magnitude (Mj) of the mainshock was 7.3. Fortunately there were no deaths caused by this earthquake, however, nearly 100 people were injured and more than 1500 houses were completely or partially destroyed by very strong ground motion in the source area.

Three aspects of this earthquake are not commonly found in other large earthquakes. It occurred in the area where (1) the maximum shear strain rate in the latest two years (1997-1999) is less than $1 \times 10^{-8} \mathrm{yr}^{-1}$ and the cumulative maximum shear strain in the past 100 years $(1883-1994)$ is less than $1 \times 10^{-5}$ (Geographical Survey Institute, 2001), (2) there was no documented active fault corresponding to the rupture surface of this earthquake and (3) swarm-like seismic activity including six moderate events with $\mathrm{Mj}=5.1-5.4$ preceded the $\mathrm{Mj}=7.3$ mainshock in 1989, 1990 and 1997.

This paper is concerned with the third point. Our purpose is to clarify the relationship between the mainshock of the 2000 Western Tottori Earthquake and the preceding swarms. First, in order to obtain accurate hypocenters, we redetermine the mainshock and aftershocks in 2000 and earthquakes in the preceding swarms with a two-step master event technique, using a combined data set from our permanent seismic stations and temporary observations which we carried out in the vicinity of the source areas (Shibutani et al., 1991,

Copy right(C) The Society of Geomagnetism and Earth, Planetary and Space Sciences (SGEPSS); The Seismological Society of Japan; The Volcanological Society of Japan; The Geodetic Society of Japan; The Japanese Society for Planetary Sciences.
1998). Then, we compare the relocated hypocenters between the seismic activity in and before 1997 and in 2000, and also compare the hypocenters with a slip distribution of the mainshock (Sekiguchi and Iwata, 2001; Iwata and Sekiguchi, 2002). The questions we want to clear up in this paper are as follows: (1) Had the preceding swarms occurred on the same fault plane as the mainshock fault of the 2000 Western Tottori Earthquake? (2) Did a preexisting fault move during the mainshock though no active fault had been recognized corresponding to the mainshock fault? (3) Was the starting point of the mainshock rupture located in the preceding swarm area? (4) Were the b-values of the preceding swarms small? (5) Was a main rupture area with large slip located in the preceding swarm area or outside?

The final goal of our study is to clarify the environment in which this earthquake occurred. We believe that this paper, as well as other studies in progress such as travel time tomography for 3-D Vp and Vs structures in the source area (Joint Group for Dense Aftershock Observation of the 2000 Tottori-ken Seibu Earthquake, 2001) will play an important rule in solving this essential problem.

\section{Overview of the Past Seismicity}

First, we examined the seismicity before the mainshock, using the earthquake catalogue compiled by the Tottori Observatory, Research Center for Earthquake Prediction, Disaster Prevention Research Institute, Kyoto University (Kishimoto et al., 1978; Nakao et al., 1991). Figure 1 shows the epicenter distribution in and around the source area. Events in the outer square $\mathrm{ABCD}$ are selected and plotted in the space-time diagrams (Fig. 2). In Fig. 2, we see 


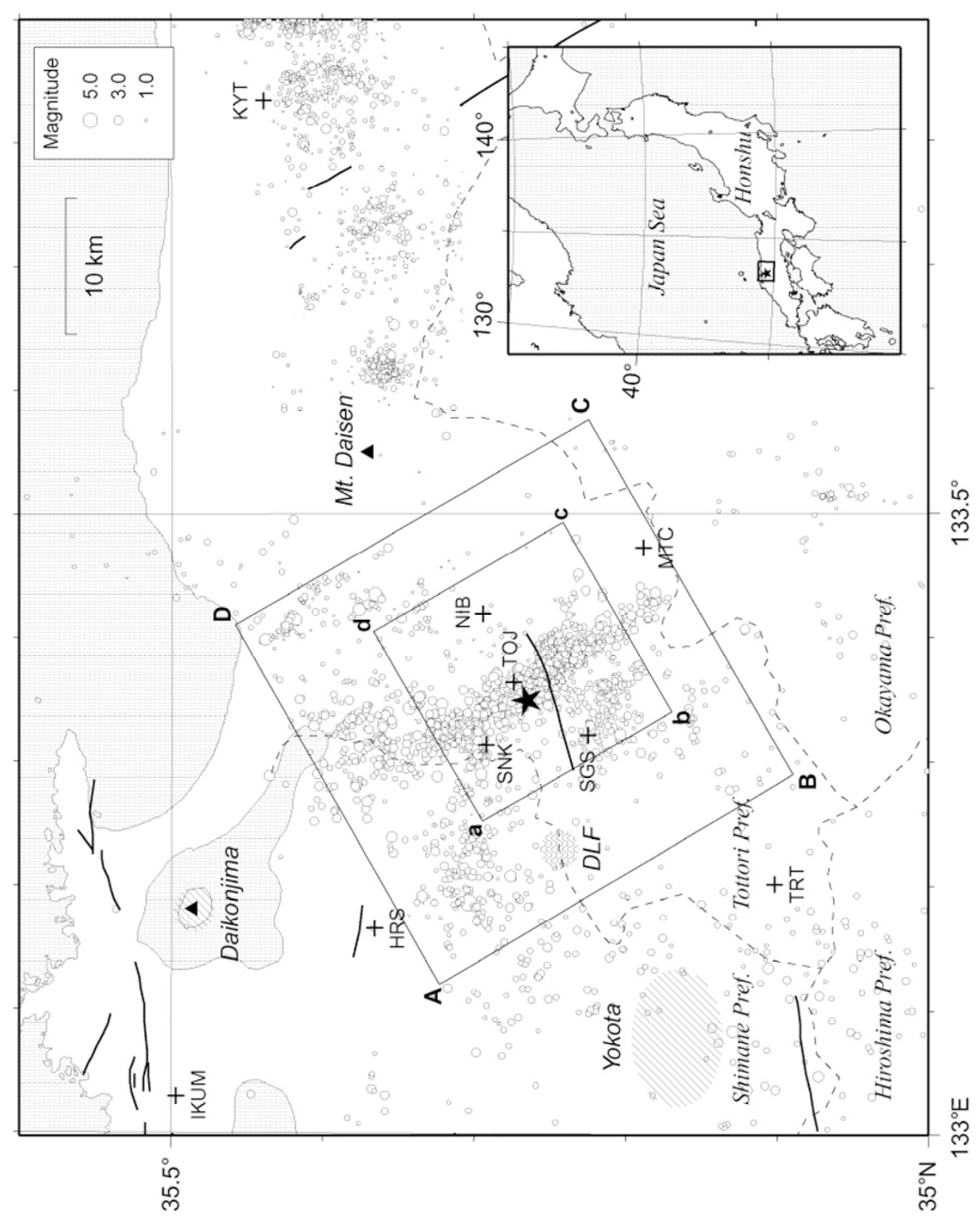

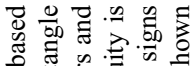

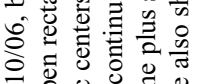

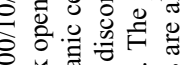

穴.

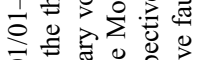

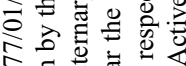

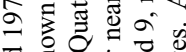

क्षे

贾

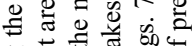

on

要

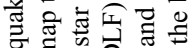

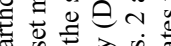

至.

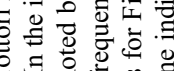

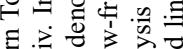

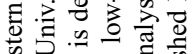

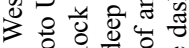

\&

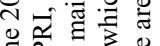

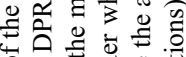

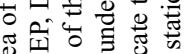

政

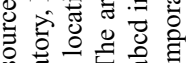

政

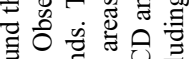

등

흥

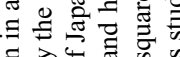

다에

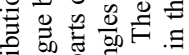

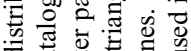

范尊

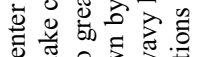

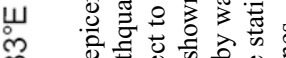

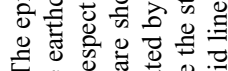

F

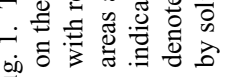




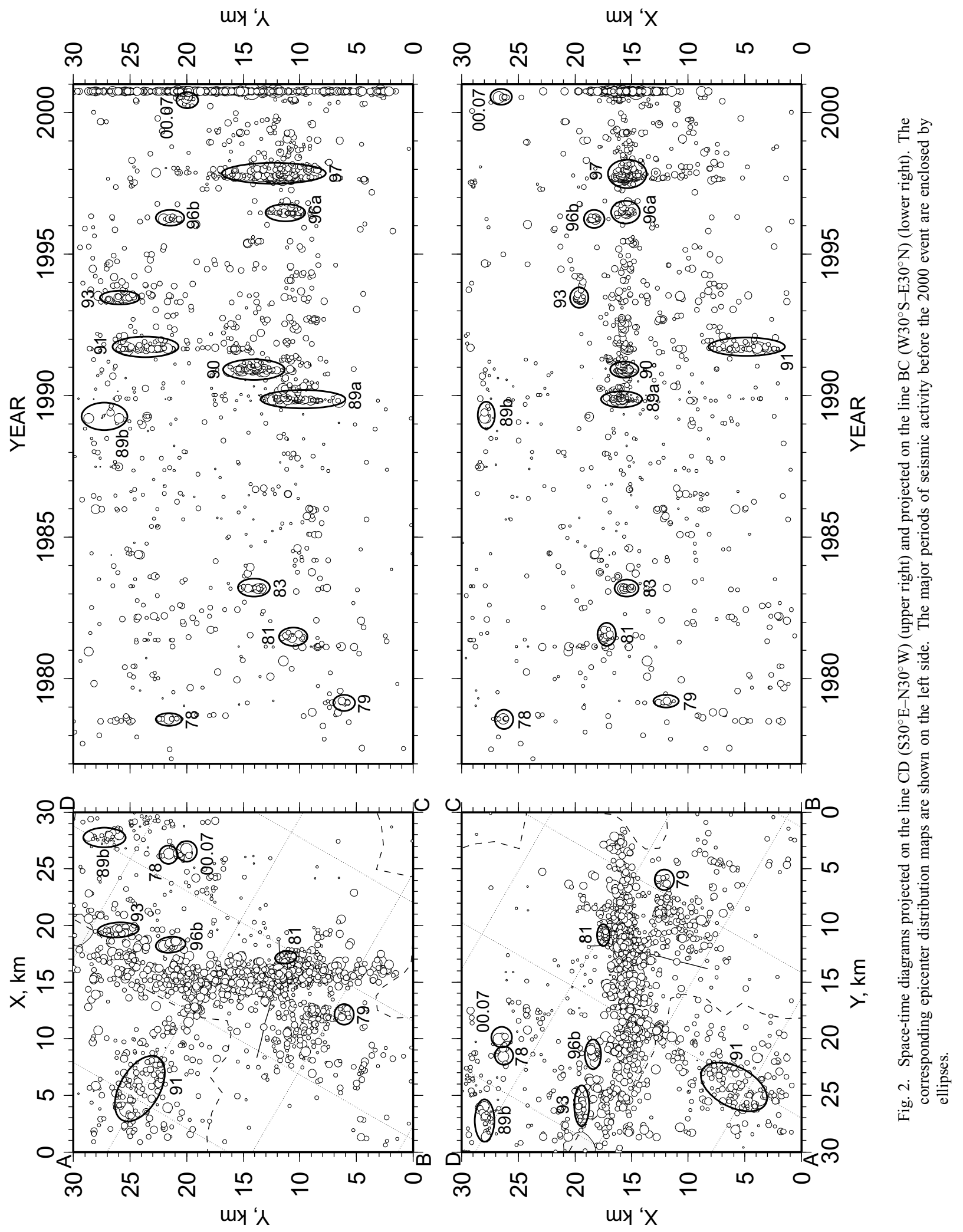



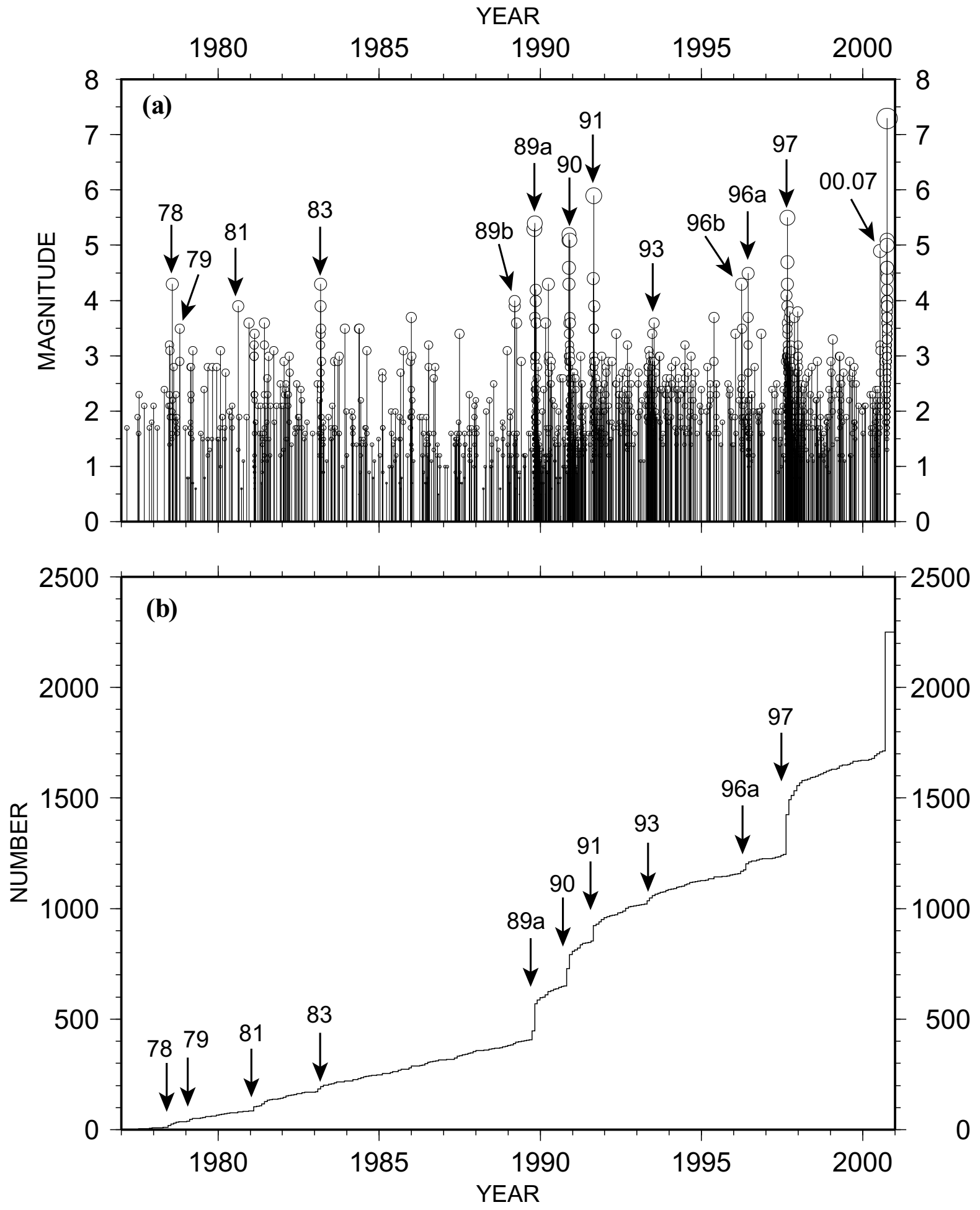

Fig. 3. (a) The magnitude-time diagram. (b) The cumulative number of events in the square ABCD in Fig. 1 is plotted as a function of time from $1977 / 01 / 01$. The major periods of activity are indicated by the arrows.

three small bursts in 1979, 1981 and 1983 that occurred close to the source area of the 2000 mainshock, with the largest events M3.9, M3.6 and M4.3, respectively (M denotes the magnitude determined by the Tottori Observatory based on an empirical relationship of the coda duration time, which was derived from the least square fitting for the linear regression between $\log$ of the coda duration time and $\mathrm{Mj}$ for 150 earthquakes with $3 \leq \mathrm{Mj} \leq 5$ (Oike, 1975)). Stronger activ- ity occurred in 1989 and 1990 which included five $\mathrm{Mj}>5$ events $(\mathrm{Mj}=5.3,5.4$ in 1989; $\mathrm{Mj}=5.1,5.2,5.1$ in 1990). Another swarm occurred in 1997 and included an $\mathrm{Mj}=5.1$ event. About a year before the 1997 swarm weaker seismic activity occurred in 1996 with the largest event M4.5. Outside the source area, there were more burst of activity in 1978 (M4.3), 1989 (M4.0), 1991 (Mj = 5.9), 1993 (M3.4), 1996 (M4.3), July 2000 (M4.9). Most of this seismicity can be 


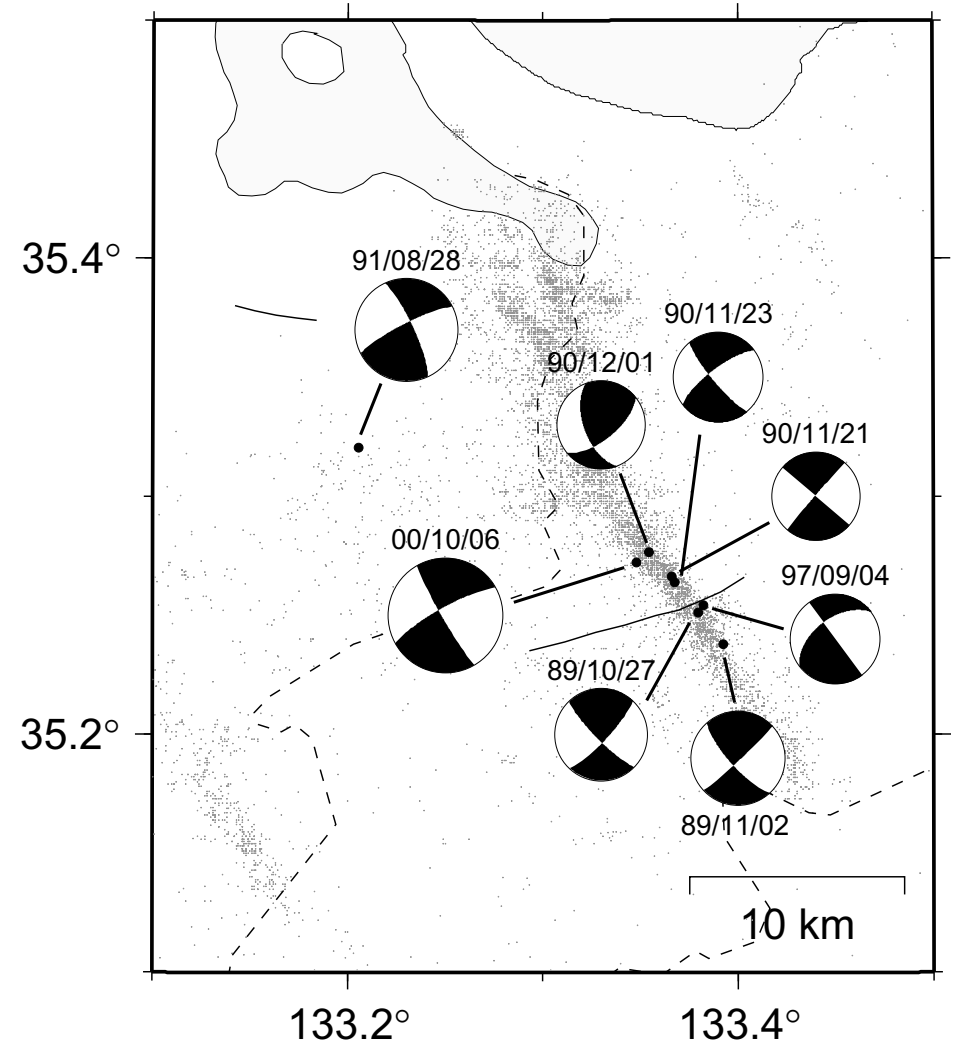

Fig. 4. Focal mechanisms for the $\mathrm{Mj}>5$ events, shown in lower hemisphere projections. The mechanism solutions in 1989 , 1990 and 1991 were determined from P-wave polarity data (Nishida et al., 1990, 1992), while those in 1997 and 2000 were determined by waveform inversions from broadband stations (Fukuyama et al., 2000, 2001). The epicenter distribution is also shown by gray dots.

categorized as the swarm activity rather than the mainshockaftershock sequences.

The selected events in Fig. 1 are plotted in the magnitudetime diagram (Fig. 3(a)) and in the cumulative curve diagram (Fig. 3(b)). In these figures we can see the changes, such as the step-wise increase in the cumulative number of the events, corresponding to the above mentioned seismic activity.

The focal mechanism solutions for the $\mathrm{Mj}>5$ events are shown in Fig. 4. They are mostly strike-slip mechanisms with a $\mathrm{P}$-axis in the $\mathrm{E}-\mathrm{W}$ direction. For the seven events in western Tottori Prefecture, the nodal plane in the NWSE direction is assumed to be the earthquake fault, because the earthquakes in each burst of activity distribute along the same direction as the nodal plane.

Figure 5 shows the magnitude-frequency diagrams for the seismic activity in 1989, 1990, 1997 and 2000. The b-values for the preceding swarm-like activity are significantly low (0.51-0.67) compared with 1.24 for the activity in 2000 . Similar examples of which precursory activity or foreshocks have a low b-value were reported for many events, such as for the 1945 Mikawa earthquake (Utsu, 1974), the 1960 Chilean earthquake (Suyehiro, 1966) and the 1987 Edgecumbe earthquake, New Zealand (Smith and Oppenheimer, 1989). Since low b-values are associated with highly stressed asperities (Wiemer and Wyss, 1997), the fact that the b-values of the preceding swarms are low might suggest that they were precursors of the mainshock in 2000 . The b-values of recent swarm-like activity in the region from central Tottori to eastern Shimane Prefecture are 0.65 for a swarm near the Daisen Volcano in 1985 (Takeuchi et al., 1986), 0.82 for activity in central Tottori Prefecture in 1983 (Tsukuda et al., 1984) and 0.80 for the activity in eastern Shimane Prefecture in 1991.

\section{The Swarm-like Activity in 1989, 1990 and 1997}

We carried out temporary seismic observations during each of these times of seismic activity. It is well known that by adding stations in the vicinity of the source area we can improve the locations of hypocenters, especially in depth. The stations used in determining the hypocenters are listed in Table 1 and shown in Fig. 6. The available stations were different among the time periods, therefore, we used a master event method (Ito and Kuroiso, 1979) which reduces the error in the hypocenters due to using different sets of stations.

The hypocenter determination was carried out by the following two steps. (1) Four events were selected from the activity in 1989, 1990, 1997 and 2000, and were relocated with the event from 1997 as the master event. (2) Events in each separate time period were relocated with the corresponding master event, which was relocated in the second step. The four master events are listed in Table 2 and shown by closed circles in Figs. 7-10.

The steps of the master event method are as follows. (1) The master event is relocated with the same stations used for the event to be located. (2) The event is located using the time residuals at each station from the first step, as the station 

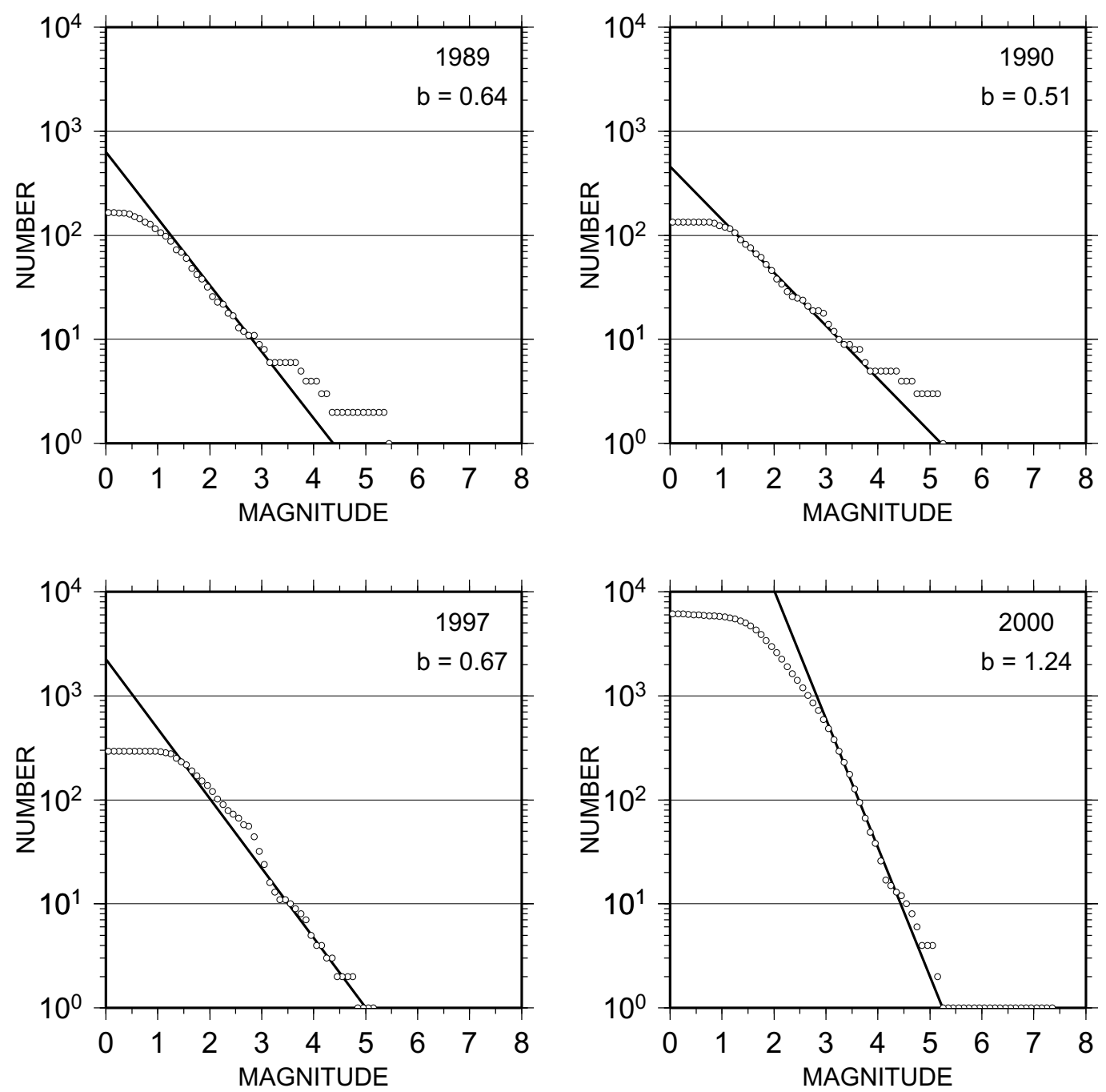

Fig. 5. Magnitude-frequency diagrams for activity in 1989, 1990, 1997 and 2000. The b-values were determined by the method of maximum likelihood estimation (Utsu, 1965). The solid lines with the slope of $-\mathrm{b}$ were fitted to the observations shown by the open circles.

corrections. (3) The relative vector from the relocated master event to the event located in the second step is added to the location of the original (unrelocated) master event. The final point in the third step gives the hypocenter of the event.

We used both P- and S-times with the weight for the Stime being $1 / 5$ of that for the P-time. The velocity model is the one used at the Tottori Observatory (Oike, 1975; Shibutani and Oike, 1989).

Errors in the relocated hypocenters were less than $0.13 \mathrm{~km}$ and $0.11 \mathrm{~km}$ in the $\mathrm{E}-\mathrm{W}$, and $\mathrm{N}-\mathrm{S}$ directions, respectively, for $90 \%$ of the events in the preceding swarms. The error in depth was less than $0.20 \mathrm{~km}$ for $75 \%$ of the events. The root mean square of the residuals in the travel times of $\mathrm{P}$ - and S-waves was less than $0.15 \mathrm{~s}$ for $90 \%$ of the events.

Figure 7 shows the hypocenter distribution of the 1989 activity. The line running nearly horizontally across the middle of the figure denotes the Kamakurayama Nanpo Fault (KNF), which is an active fault, recognized with the lowest reliability (III) (Research Group for Active Faults of Japan, 1991). The main feature of the distribution is that $2 / 3$ of the 1989 events were located south of the KNF. Two earth- quakes with $\mathrm{Mj}>5$ occurred during this time period. The first event $(\mathrm{Mj}=5.3,1989 / 10 / 27)$ was located just north of the fault, while the second one $(\mathrm{Mj}=5.4,1989 / 11 / 02)$ was located on the southeast edge of the distribution.

Figure 8 shows the hypocenter distribution of the 1990 activity. In contrast to the 1989 activity, the distribution of the 1990 activity was limited to the area north of the KNF. Three $\mathrm{Mj}>5$ events occurred on 1990/11/21 $(\mathrm{Mj}=5.1)$, $1990 / 11 / 23(\mathrm{Mj}=5.2)$ and 1990/12/01 $(\mathrm{Mj}=5.1)$. The first and second events were located on the southeast edge of the distribution, while the third one was located close to the northwest edge.

Figure 9 shows the hypocenter distribution of the 1997 activity. In this case the hypocenters were spread across the KNF. There was an event with Mj > 5 on 1997/09/04 $(\mathrm{Mj}=5.1)$ which was located just south of the fault. The events in the earlier stage of the 1997 activity were localized near the largest event.

Therefore, a common feature of the three periods of seismic activity is that they began near the KNF and spread outward to the northwest or to the southeast. 


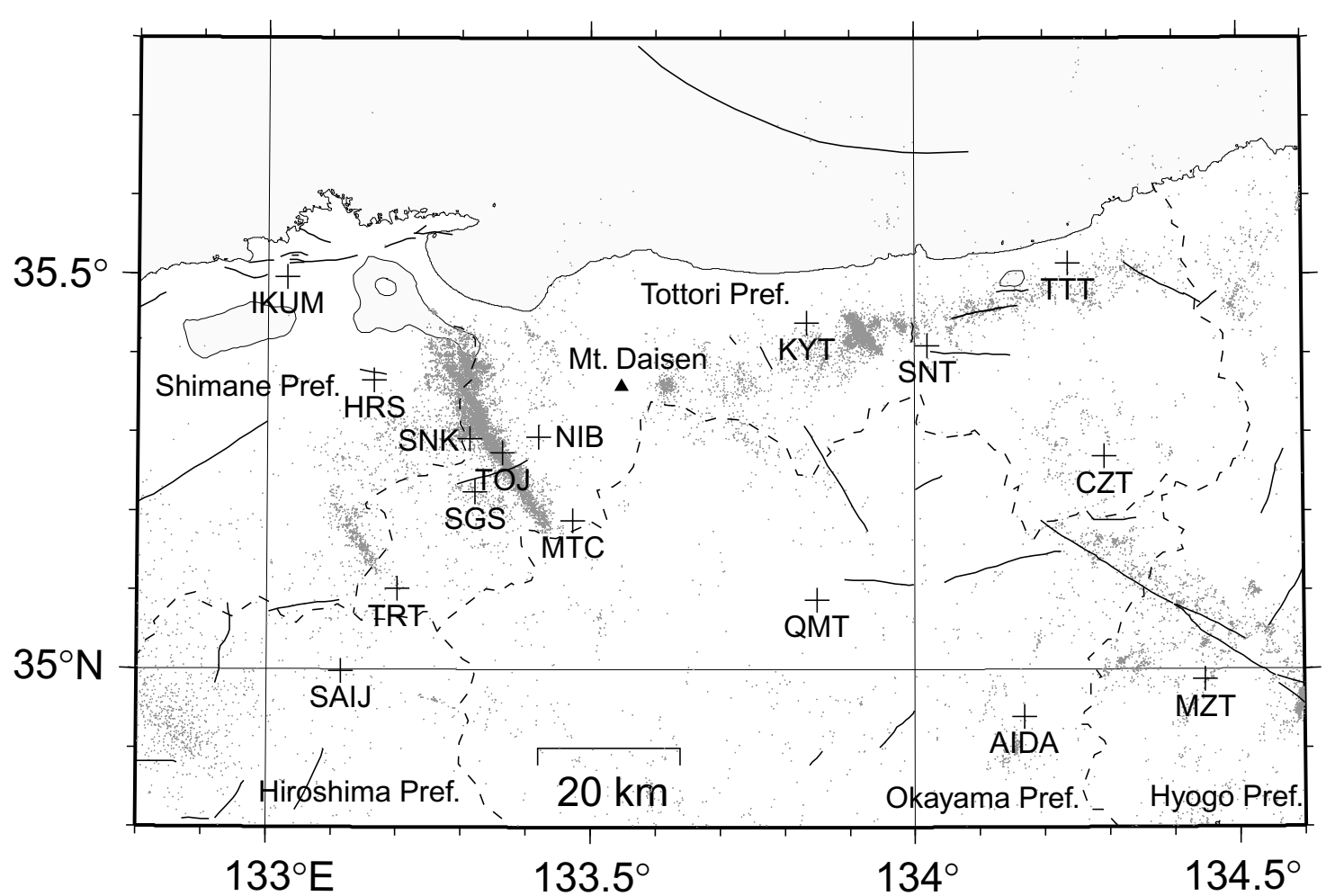

Fig. 6. Station distribution map. The locations of the stations are listed in Table 1. The epicenter distribution is shown by gray dots.

Table 1. List of the stations used in this study.

\begin{tabular}{lcccl}
\hline Code & Longitude & Latitude & Height, $\mathrm{m}$ & \multicolumn{1}{c}{ Remarks } \\
\hline HRS & 133.1655 & 35.3659 & 90 & TF, 1989 \\
TOJ & 133.3640 & 35.2743 & 295 & TF, 1989 \\
NIB & 133.4192 & 35.2948 & 150 & TF, 1990 \\
SGS & 133.3214 & 35.2254 & 420 & TF, 1990 \\
SNK & 133.3136 & 35.2924 & 210 & TF, 1990; TN, 1997, 2000 \\
MTC & 133.4724 & 35.1890 & 430 & TN, 1997, 2000 \\
CZT & 134.2935 & 35.2695 & 300 & $\mathrm{P}$ \\
HMT & 135.0435 & 35.2265 & 250 & $\mathrm{P}$ \\
IZT & 134.8876 & 34.9722 & 230 & $\mathrm{P}$ \\
KYT & 133.8338 & 35.4392 & 100 & $\mathrm{P}$ \\
MZT & 134.4472 & 34.9869 & 150 & $\mathrm{P}$ \\
OYT & 134.6658 & 35.3218 & 230 & $\mathrm{P}$ \\
QMT & 133.8491 & 35.0885 & 330 & $\mathrm{P}$ \\
SNT & 134.0202 & 35.4105 & 200 & $\mathrm{P}$ \\
TRT & 133.2016 & 35.1022 & 480 & $\mathrm{P}$ \\
TTT & 134.2377 & 35.5147 & 10 & $\mathrm{P}$ \\
AIDA & 134.1683 & 34.9400 & 170 & $\mathrm{P}, \mathrm{JMA}$ \\
IKUM & 133.0300 & 35.4967 & 20 & $\mathrm{P}, \mathrm{JMA}$ \\
SAIJ & 133.1150 & 34.9983 & 480 & $\mathrm{P}, \mathrm{JMA}$ \\
\hline
\end{tabular}

TF: temporary offline station; TN: temporary online station; P: permanent online station. The temporary stations are specified the year of operation. JMA denotes that the station is operated by JMA. The other permanent stations belong to Tottori Observatory, RCEP, DPRI, Kyoto Univ. 

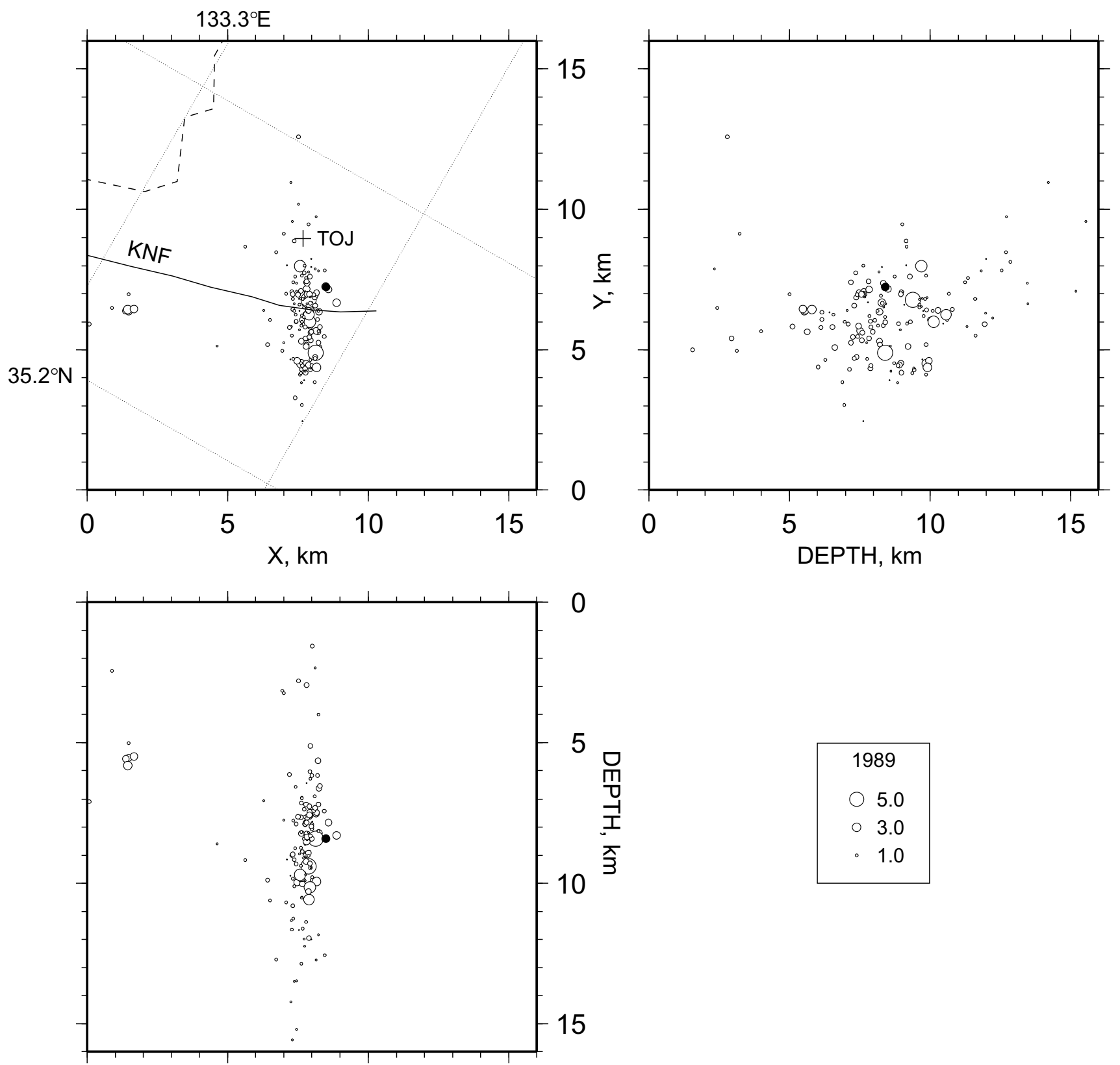

0

5

\begin{tabular}{|c|c|}
\hline 㽞 & 1989 \\
\hline 7 & $\bigcirc 5.0$ \\
\hline I & $\begin{array}{lll}\circ & 3.0\end{array}$ \\
\hline$\overline{3}$ & $\cdot 1.0$ \\
\hline
\end{tabular}

Fig. 7. The hypocenter distribution for the activity in 1989. The area of the epicenter map in the upper left corresponds to the square abcd in Fig. 1. The two depth distributions are shown. The upper right is projected on the line cd $\left(\mathrm{S} 30^{\circ} \mathrm{E}-\mathrm{N} 30^{\circ} \mathrm{W}\right)$, while the lower left is projected on the line bc $\left(\mathrm{W} 30^{\circ} \mathrm{S}-\mathrm{E} 30^{\circ} \mathrm{N}\right)$. The hypocenters were relocated by the master event technique. The master event is shown by the closed circles. The line labeled with KNF denotes the Kamakurayama Nanpo Fault.

Table 2. List of the master events.

\begin{tabular}{ccccccc}
\hline Date & Time & Longitude & Latitude & Depth, km & Magnitude & RMS \\
\hline $1989 / 11 / 21$ & $17: 40: 40.16$ & 133.3812 & 35.2645 & 8.42 & 2.6 & 0.12 \\
$1990 / 12 / 03$ & $02: 03: 01.65$ & 133.3533 & 35.2847 & 7.33 & 1.8 & 0.09 \\
$1997 / 10 / 31$ & $19: 11: 27.49$ & 133.3744 & 35.2653 & 6.47 & 2.2 & 0.00 \\
$2000 / 10 / 16$ & $00: 05: 00.04$ & 133.3548 & 35.2796 & 8.99 & 2.6 & 0.09 \\
\hline
\end{tabular}

RMS means the root mean square of the residuals in the travel times of P- and S-waves. 

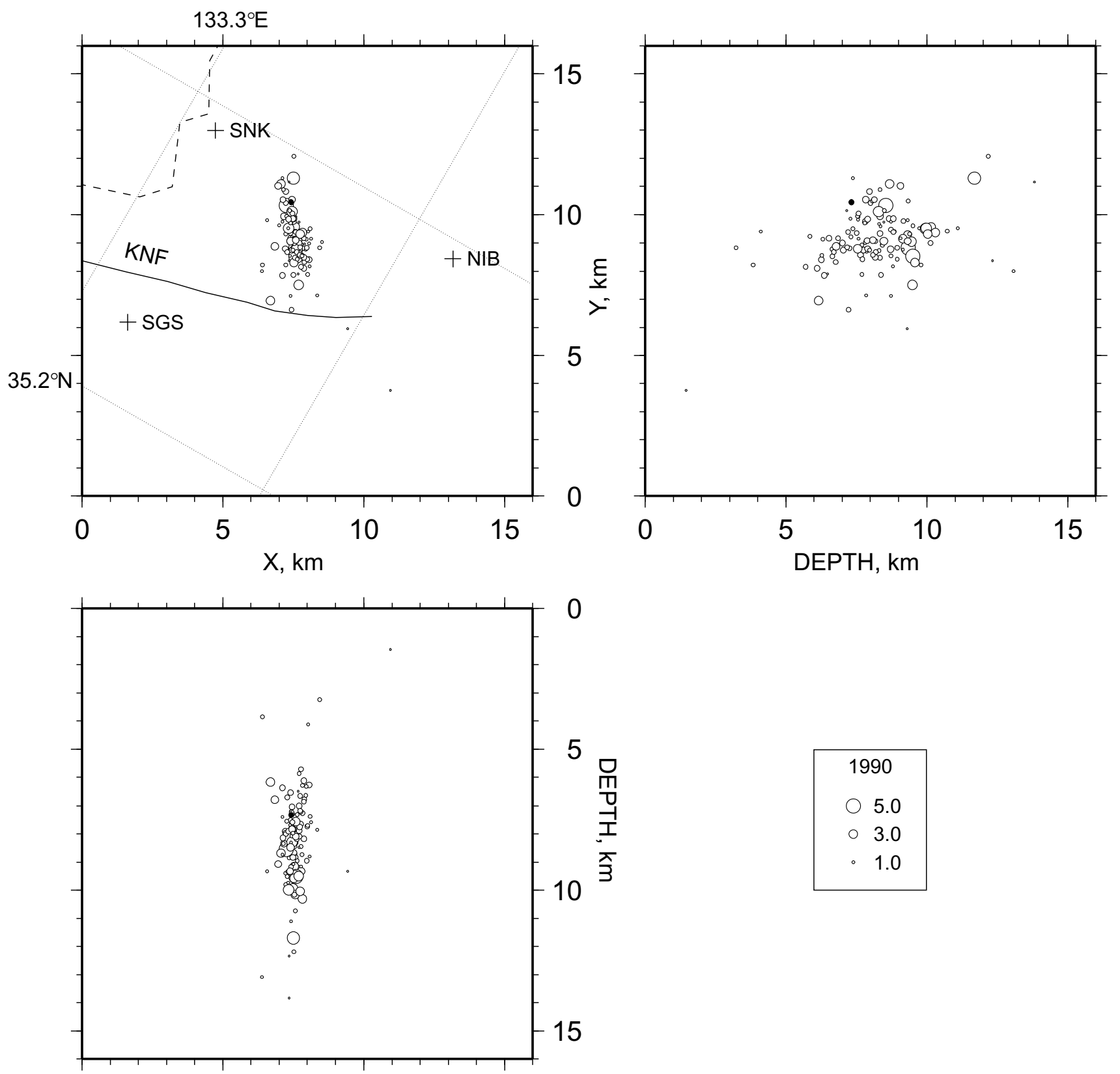

5

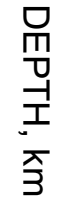

15

Fig. 8. The hypocenter distribution for the activity in 1990. The area of the epicenter map in the upper left corresponds to the square abcd in Fig. 1. The two depth distributions are shown. The upper right is projected on the line cd $\left(\mathrm{S} 30^{\circ} \mathrm{E}-\mathrm{N} 30^{\circ} \mathrm{W}\right)$, while the lower left is projected on the line bc $\left(\mathrm{W} 30^{\circ} \mathrm{S}-\mathrm{E} 30^{\circ} \mathrm{N}\right)$. The hypocenters were relocated by the master event technique. The master event is shown by the closed circles. The line labeled with KNF denotes the Kamakurayama Nanpo Fault.

\section{The Relationship between the Preceding Seis- micity and the Mainshock in 2000}

The epicenter distributions of the three preceding periods of seismicity and the mainshock in 2000 are compared in Figs. 10 and 11. The epicenters of the four periods of activity distribute along a line running in the $\mathrm{N} 30^{\circ} \mathrm{W}-\mathrm{S} 30^{\circ} \mathrm{E}$ direction. This direction agrees with one of the nodal planes of the $\mathrm{Mj}>5$ events shown in Fig. 4. This suggests that the preceding activity occurred on the same fault plane as that of the mainshock in 2000. Most of the epicenters of the activity in 1989 and 1990 do not overlap. The activity in 1990 seems to have expanded to the northwest direction from the area of the 1989 activity. The initiation point of the 2000 mainshock, which is denoted by the arrow in the lower right figure, is located between the activity in 1989 and 1990.

Figure 12 shows the depth distributions of the hypocenters of the four periods of seismicity in the cross section along the $\mathrm{N} 30^{\circ} \mathrm{W}-\mathrm{S} 30^{\circ} \mathrm{E}$ direction. In the epicenter distribution maps, the activity in 1997 seemed to overlap with the previous activity in 1989 and 1990 . However, most of the hypocenters of the 1997 activity are shallower than $8 \mathrm{~km}$, whereas the major events in 1989 and 1990 are located deeper than that depth. In the 2000 activity few aftershocks are found in the area where the preceding seismicity occurred. This suggests that the four periods of activity occurred on the different parts on the same fault plane. 

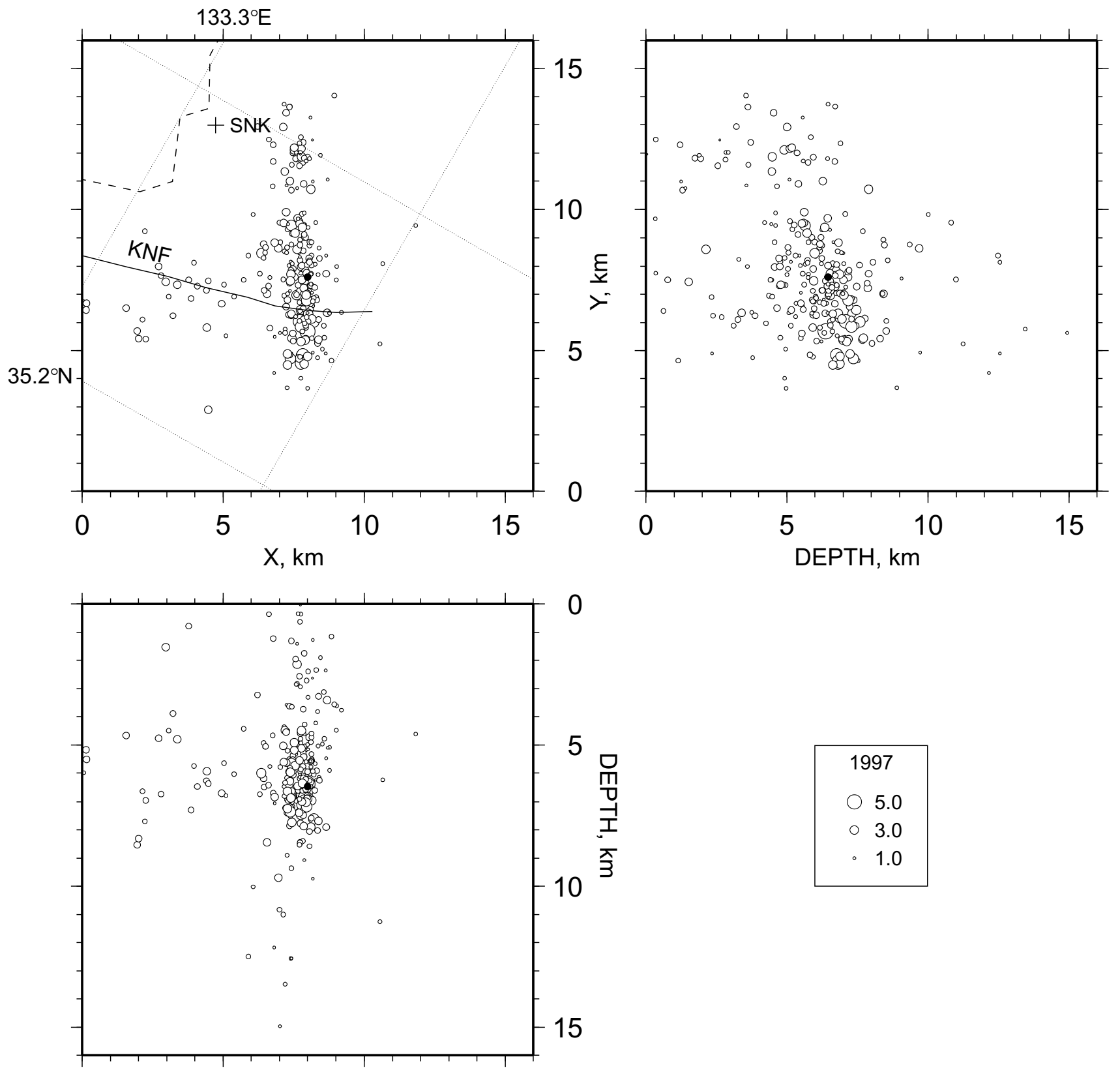

0

5

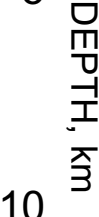

15

Fig. 9. The hypocenter distribution for the activity in 1997. The area of the epicenter map in the upper left corresponds to the square abcd in Fig. 1. The two depth distributions are shown. The upper right is projected on the line cd $\left(\mathrm{S} 30^{\circ} \mathrm{E}-\mathrm{N} 30^{\circ} \mathrm{W}\right)$, while the lower left is projected on the line bc $\left(\mathrm{W} 30^{\circ} \mathrm{S}-\mathrm{E} 30^{\circ} \mathrm{N}\right)$. The hypocenters were relocated by the master event technique. The master event is shown by the closed circles. The line labeled with KNF denotes the Kamakurayama Nanpo Fault.

In Fig. 13 we compare the depth distribution of the previous seismicity with the slip distribution during the 2000 mainshock, which was obtained by a joint inversion of seismic waveforms from strong motion stations and crustal movement data from GPS stations around the source area (Sekiguchi and Iwata, 2001; Iwata and Sekiguchi, 2002). The slip is relatively small in the area where the previous seismicity occurred. In contrast, areas of large slip occur on the southeast side and above the region of previous seismicity. It was reported that the 2000 mainshock had an initial rupture stage with relatively small slip $(\sim 1 \mathrm{~m})$ continuing for about $3 \mathrm{~s}$ (Umeda et al., 2001). The starting point of the initial rupture was located in the area of the previous seis- micity. Then, the rupture developed in a second stage with large slip (2-4 m) in the area toward the southeast.

\section{Discussions}

The source area of the 2000 Western Tottori Earthquake and the preceding swarms are located between the Daisen Volcano, which was active during the Pleistocene, and the Yokota alkali basaltic area, which was active in the Early Pleistocene. Several deep low-frequency earthquakes were found just above the Moho discontinuity near the source area (Ohmi and Obara, 2001). This suggests that the 2000 mainshock as well as the preceding seismic activity might be triggered by crustal fluids. The Matsushiro Earthquake Swarm 

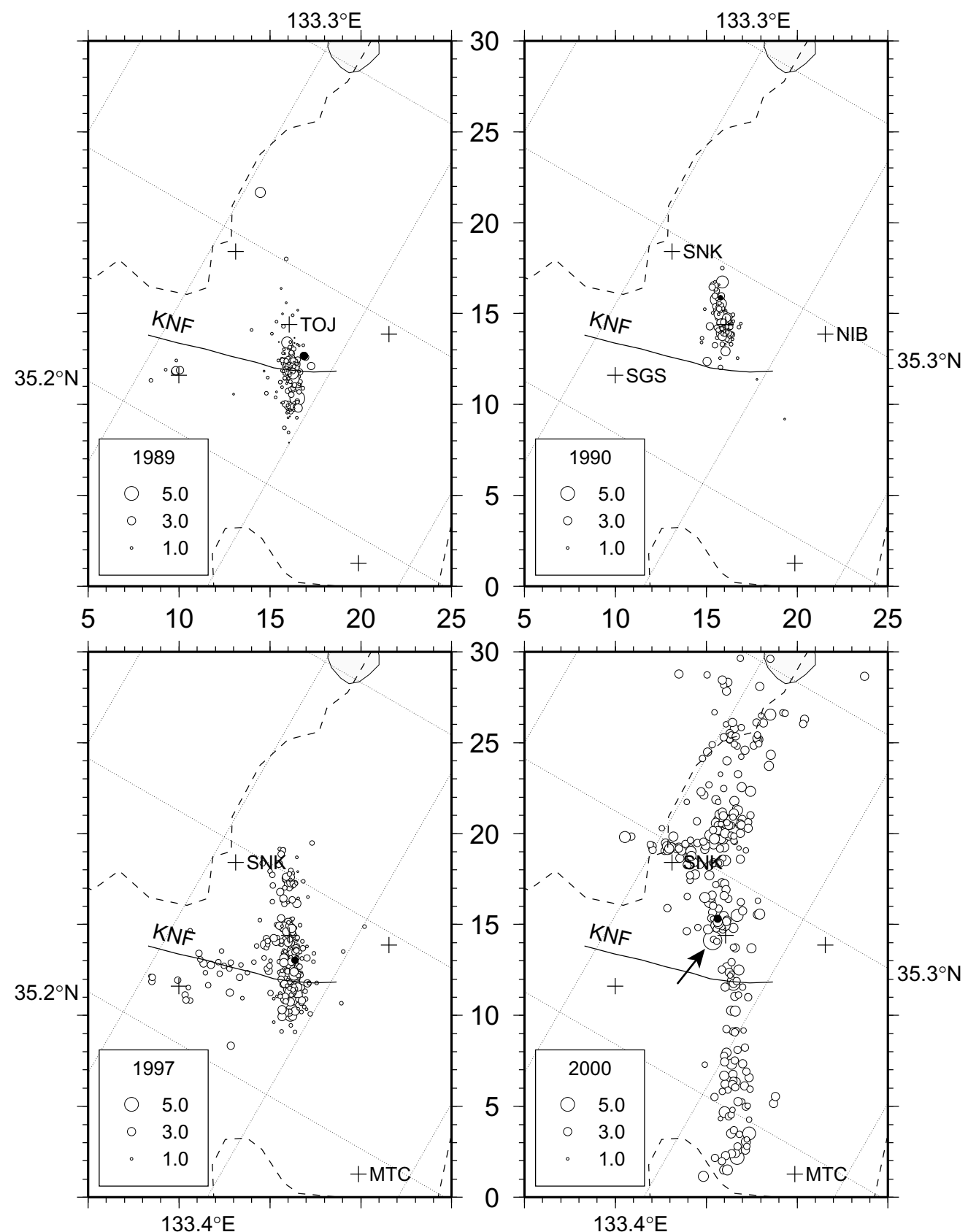

Fig. 10. Comparison of the epicenter distributions among the activity in 1989, 1990, 1997 and 2000. The maps are rotated clockwise by 30 degrees Closed circles denote the master event in each activity. The arrow in the lower right figure indicates the epicenter of the mainshock in 2000 . The line labeled with KNF in each figure denotes the Kamakurayama Nanpo Fault.

from 1965 to 1967 is the most famous example that shows ground water could play an important part in the occurrence of an earthquake swarm (e.g. Ohtake, 1976; Mogi, 1988). Earthquake swarms off the Izu Peninsula in 1989 and 1997 and a strong swarm activity northwest Miyakejima Island in 2000 were explained by intrusions of magma (e.g. Okada and Yamamoto, 1991; Sakai et al., 2001). Nakamura et al. (1996) suggested that an earthquake swarm in Inagawa Town near the 1995 Hyogo-ken Nambu (Kobe) Earthquake was caused by vertical fluid flow in the upper crust. In the source area of the 1991 swarm in eastern Shimane Prefecture, which is in an adjacent area west of the 2000 Western Tottori Earthquake, seismic phases that seemed to be reflected waves were found (Nakao et al., 1993). It is necessary for us to investigate in detail such reflected waves found in and around the source area of the 2000 mainshock, to depict physical properties of reflectors, and to discuss the relationship between deep underground fluid and the occurrence of the mainshock.

The 1984 Western Nagano Prefecture Earthquake has similar features to the 2000 Western Tottori Earthquake. First, the 1984 mainshock $(\mathrm{Mj}=6.8)$ was located near Ontake volcano, which became active in the Middle Pleistocene and whose latest eruption occurred in 1979. Second, the mainshock was preceded by two earthquake swarms, one in 1976 and the other from 1978 to 1984 . The second swarm occurred in an adjacent area east of the first one, and it can 


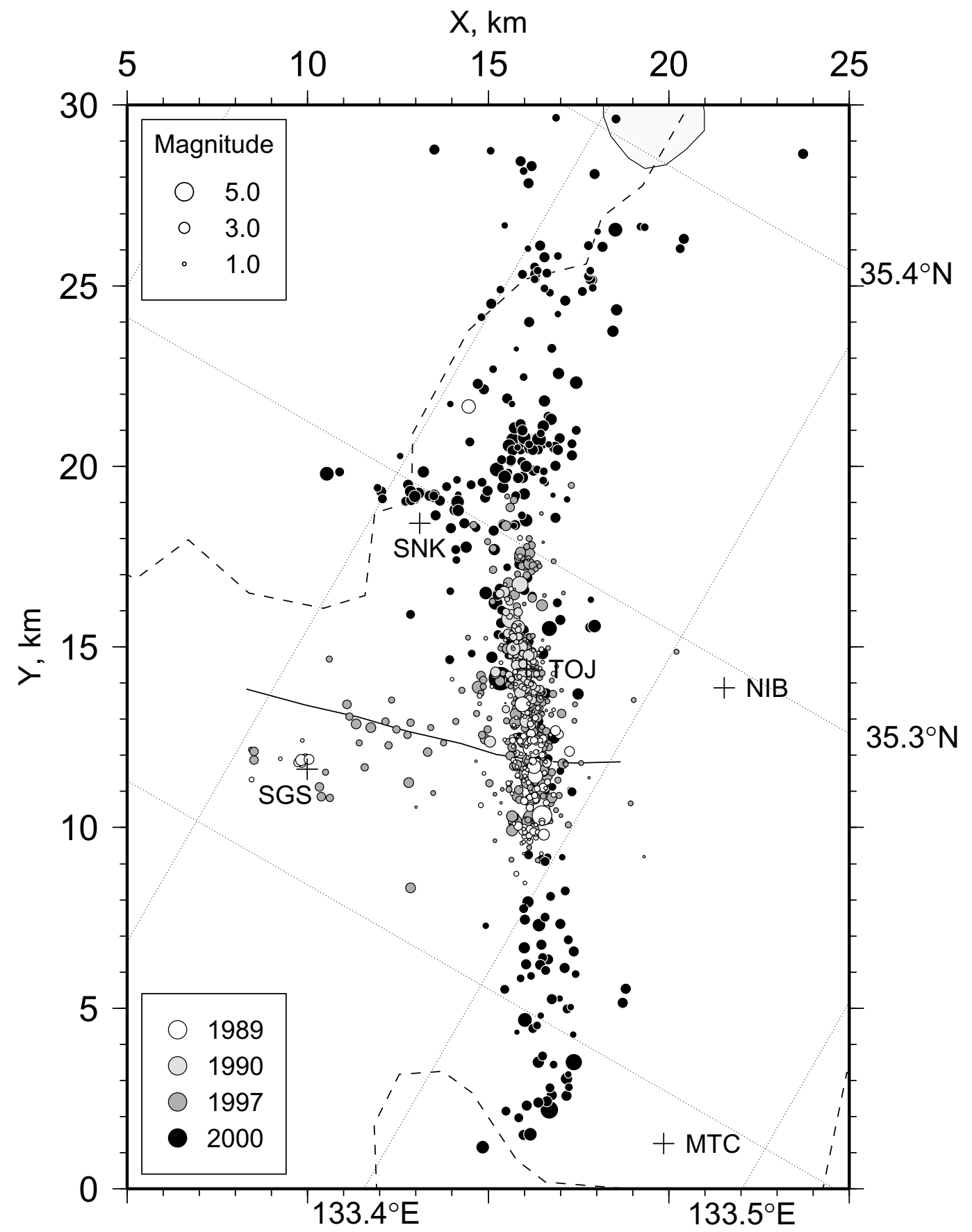

Fig. 11. Comparison of the epicenter distributions for the seismic activity in 1989, 1990, 1997 and 2000. The maps are rotated clockwise by 30 degrees. The epicenters in the different time periods are shown by varying shades of gray scale, and are overwritten in order of 2000, 1997, 1990 and 1989.

be divided into northern and southern clusters. The 1984 mainshock was located just at the place surrounded by the three clusters (Aoki, 1987; Ooida et al., 1989). As shown in Figs. 10 and 12, the mainshock of the 2000 Western Tottori Earthquake also started at the place surrounded by the 1989, 1990 and 1997 swarms. Although the events in the swarms preceding the 1984 Western Nagano Prefecture Earthquake did not concentrate on the vicinity of the fault surface of the 1984 mainshock, Aoki (1987) suggested that the mainshock occurred on an preexisting fault that was a boundary between the northern and southern clusters of the second swarm. In the case of the 2000 Western Tottori Earthquake, our re- sults strongly suggest an preexisting fault since the preceding three swarms occurred on the same fault plane as the 2000 mainshock.

We showed in the second section that the b-values of the preceding swarms were low $(0.51-0.67)$ compared with 1.24 for the aftershocks in 2000 or $0.80-0.82$ for recent swarmlike activity in the neighboring areas, and in the fourth section that the starting point of the 2000 mainshock was located in the area of the preceding swarms. The low b-values of the preceding swarms probably indicate that the stress level in the area was high (Scholz, 1968; Wyss, 1973). The 2000 mainshock initiated in the highly stressed area. Westerhaus 

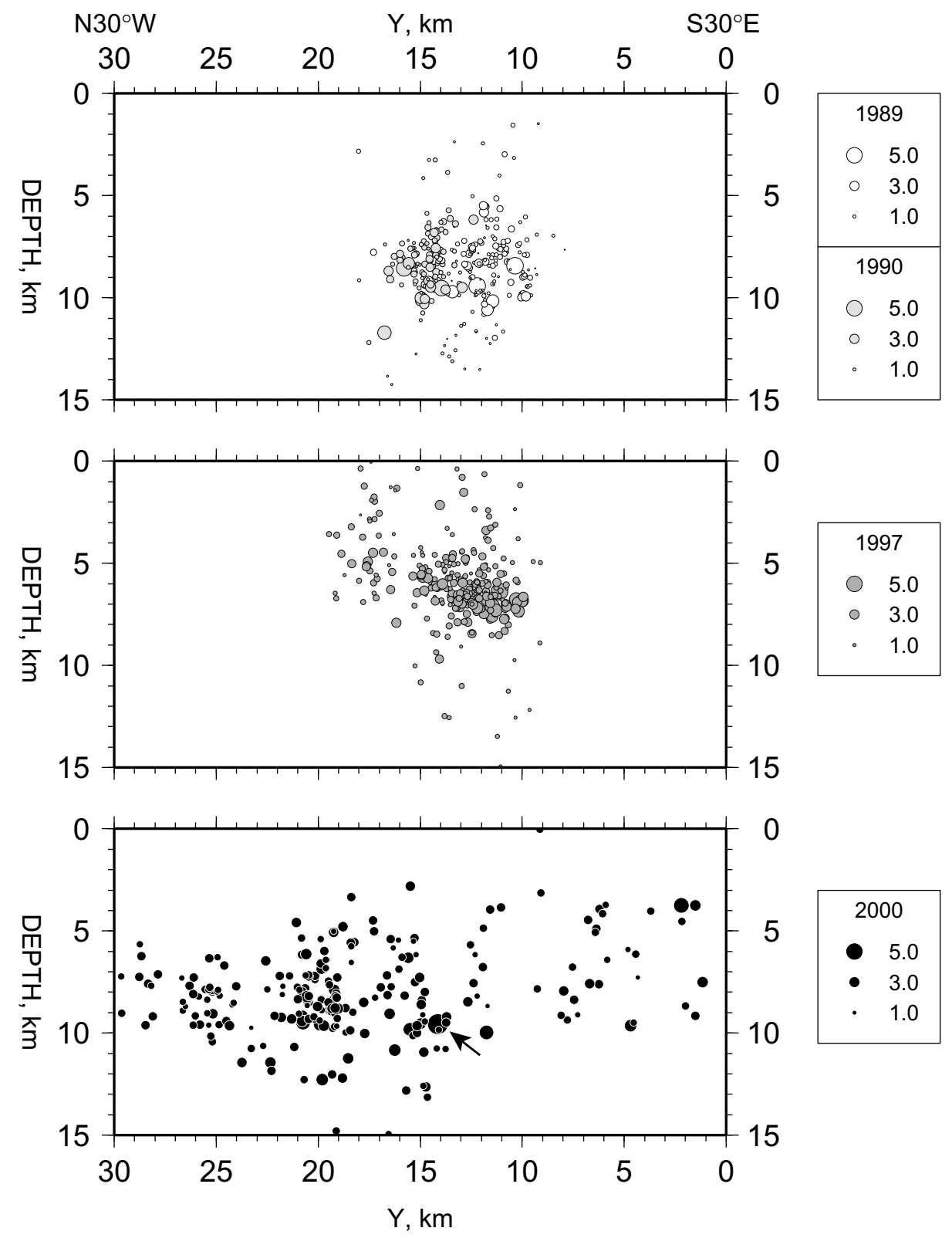

Fig. 12. Comparison of the depth distributions for the seismic activity in 1989 (upper), 1990 (upper), 1997 (middle) and 2000 (lower). The hypocenters are projected on the line $\mathrm{CD}\left(\mathrm{S} 30^{\circ} \mathrm{E}-\mathrm{N} 30^{\circ} \mathrm{W}\right)$ in Fig. 1, and are shown with the same shades of gray scale as in Fig. 11. The arrow in the lower figure indicates the epicenter of the mainshock in 2000.

et al. (2002) showed that the rupture initiation of the 1999 Izmit earthquake was also located near the site of the lowest b-values. Lei et al. (2000) showed from a series of experiments on mudstone with quartz veins that: (1) most of $\mathrm{AE}$ occurred at the intersections of faults and the veins which played a role of strong asperities on the faults; (2) the b-value decreased with increasing AE rate. We can draw a good analogy between the experimental results and the above features observed for the 2000 Western Tottori Earthquake.

As mentioned previously, the 2000 Western Tottori Earthquake occurred in an area where both the strain rate in the latest two years and the cumulative strain in the past 100 years were relatively small. This means that there were not large change in the strain or stress conditions between this event and the preceding seismic activity in 1989, 1990 and 1997. The question arises why did the event in 2000 grow into a large $\mathrm{Mj}=7$ class earthquake, while the previous events stopped as $\mathrm{Mj}=5$ class earthquakes? Did the previous events have the potential to become large earthquakes? What stopped the rupture of the $\mathrm{Mj}=5$ class events in 1989 , 1990 and 1997? Although these questions are essential for earthquake prediction studies, so far we do not have enough knowledge to give a complete set of answers.

To help answer these questions, we must investigate whether an initial stage exists in the rupture of the previous $\mathrm{Mj}=5$ class events. This will give us important information in considering how the rupture stopped before developing into large events. We must also investigate the $3-\mathrm{D}$ velocity structure in the source area using tomographic inversions with the data from the dense aftershock observation. This will reveal heterogeneities in the structure along the fault plane that might control the rupture propagation. 


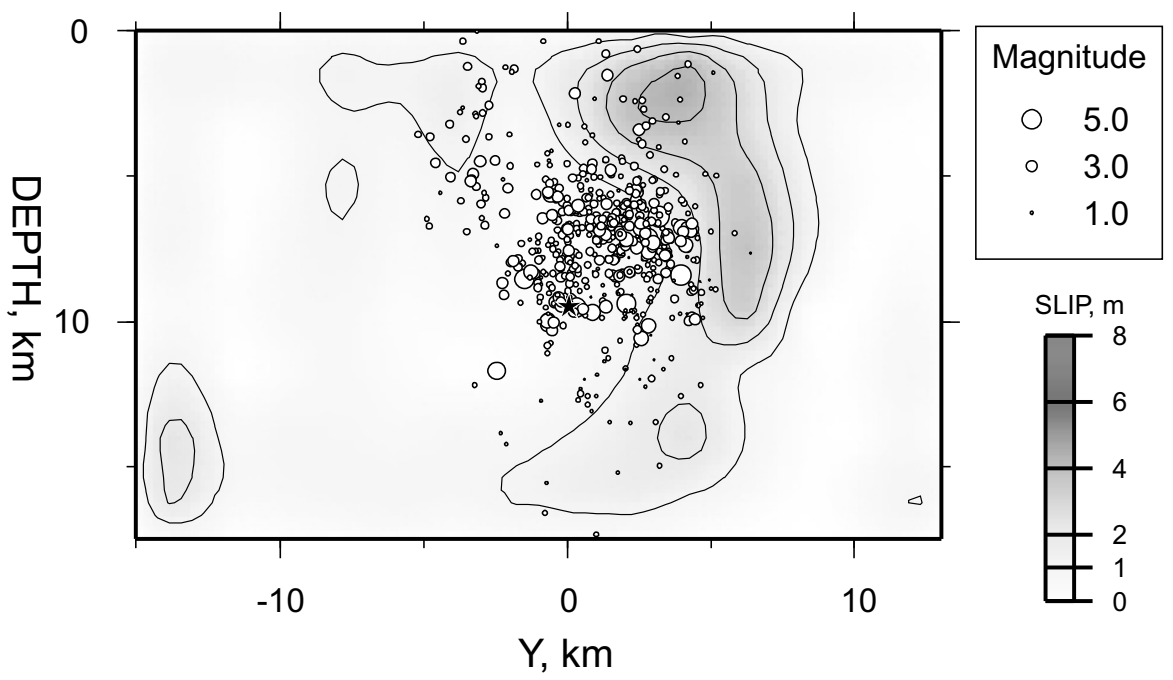

Fig. 13. Comparison between the depth distribution of the preceding seismicity in 1989, 1990 and 1997 and the slip distribution along the fault plane of the mainshock in 2000. The interval of the slip contour is $1 \mathrm{~m}$. The starting point of the mainshock rupture is denoted by the star.

\section{Conclusions}

In this study we investigated the relationship between the mainshock of the 2000 Western Tottori Earthquake and the preceding swarms in 1989, 1990 and 1997. We clarified that (1) the 2000 Western Tottori Earthquake was generated by rupture on a preexisting fault, (2) the three preceding swarms occurred in areas adjacent to each other on the preexisting fault, (3) the b-values of the preceding swarms were low $(0.51-0.67)$, indicating that the area was under highly stressed conditions, and (4) the rupture of the mainshock in 2000 initiated in the area of the preceding activity, propagating with relatively small slip for the first three seconds, and it developed to main rupture with larger slip (2-4 m) in an area to the southeast of the preceding swarms.

Acknowledgments. The authors are grateful to people who supported our temporary observations at the stations: HRS (Sohudani, Hirose Town), TOJ (Tojo, Saihaku Town), NIB (Nibu, Mizoguchi Town), SGS (Sugesawa, Nichinan Town), SNK (Shimonakatani, Saihaku Town) and MTC (Mitsuchi, Hino Town). We thank Jim Mori for his comments that were helpful to revise the manuscript. We thank Keiichi Tadokoro who helped us to set up instruments at temporary stations in 1997 and Norio Hirano who supported us by checking waveform data from online temporary stations. We also thank Shiro Ohmi for his help in accessing the earthquake database in RCEP. The data from the three JMA stations, AIDA, IKUM and SAIJ were used in the hypocenter relocation of the 2000 activity. General Mapping Tool (Wessel and Smith, 1991) was used for drawing figures. Comments by two anonymous reviewers helped improve the manuscript.

\section{References}

Aoki, H., The 1984 Western Nagano Prefecture Earthquake, Proc. Earthq. Predict. Res. Symposium (1987), 109-114, 1987 (in Japanese with English abstract).

Fukuyama, E., M. Ishida, S. Horiuchi, H. Inoue, S. Hori, S. Sekiguchi, A. Kubo, H. Kawai, H. Murakami, and K. Nonomura, NIED Seismic Moment Tensor Catalogue January-December, 1997, Technical Note Nat' Res. Inst. Earth Sci. Disas. Prev., 205, 1-35, 2000.

Fukuyama, E., M. Ishida, S. Horiuchi, H. Inoue, S. Hori, S. Sekiguchi, T. Eguchi, A. Kubo, H. Kawai, H. Murakami, S. Yamamoto, and K. Nonomura, NIED Seismic Moment Tensor Catalogue January-
December, 2000, Technical Note Nat'l Res. Inst. Earth Sci. Disas. Prev., 217, 1-131, 2001

Geographical Survey Institute, Crustal movements in the Chugoku district, Rep. Coord. Comm. Earthq. Predict., 65, 592-618, 2001 (in Japanese).

Ito, K. and A. Kuroiso, Detailed spatial distributions of foreshock and aftershock activities of small earthquakes, Zisin (J. Seismol. Soc. Jpn.), 32, 317-327, 1979 (in Japanese with English abstract).

Iwata, T. and H. Sekiguchi, Source inversion of recent earthquakes using strong motion records, in a special issue on Strong Motion Prediction, Chikyu Monthly, 37, 47-55, 2002 (in Japanese).

Joint Group for Dense Aftershock Observation of the 2000 Tottori-ken Seibu Earthquake, Aftershock distribution of the 2000 Tottori-ken Seibu Earthquake determined precisely by dense aftershock observation, Abst., 2001 Jpn. Earth Planet. Sci. Joint Meeting, S3-005, 2001 (in Japanese with English abstract).

Kishimoto, Y., K. Oike, K. Watanabe, T. Tsukuda, N. Hirano, and S. Nakao, On the telemeter observation system of the Tottori and the Hokuriku Micro-earthquake Observatory, Zisin (J. Seismol. Soc. Jpn.), 31, 265 274, 1978 (in Japanese with English abstract).

Lei, X.-L., O. Nishizawa, K. Kusunose, A. Cho, T. Satoh, and O. Nishizawa, Comprehensive failure of mudstone samples containing quartz veins using rapid AE monitoring: the role of asperities, Tectonophys., 328, 329340,2000

Mogi, K., The mechanism of the occurrence of the Matsushiro earthquake swarm in central Japan and its relation to the 1964 Niigata earthquake, Tectonophys., 159, 109-119, 1988.

Nakamura, M., M. Ando, K. Kusunose, and T. Sato, Depth-dependent crustal anisotropy at Midwestern Honshu, Japan, Geophys. Res. Lett., 23, 3417-3420, 1996

Nakao, S., T. Shibutani, R. Nishida, T. Tsukuda, and K. Oike, Relation between seismic gaps and occurrence of earthquakes in active seismic zones, Annu. Disas. Prev. Res. Inst., Kyoto Univ., 34B-1, 231-251, 1991 (in Japanese with English abstract).

Nakao, S., R. Nishida, and Y. Umeda, Seismic activity on the border of Tottori-Shimane Prefecture, Annu. Disas. Prev. Res. Inst., Kyoto Univ., 36B-1, 269-278, 1993 (in Japanese with English abstract).

Nishida, R., T. Shibutani, S. Nakao, N. Koizumi, and F. Takeuchi, On the earthquake swarm occurred in western Tottori Pref., 1989, Program. Abst., Seism. Soc. Jpn., 1, 95, 1990 (in Japanese).

Nishida, R., T. Shibutani, N. Koizumi, S. Nakao, Y. Umeda, K. Matsumura, and T. Mori, Seismic activity in and around the east of Shimane Pref. (On temporary observation of earthquake of $\mathrm{M}=5.9$ on Aug. 28, 1991), Program. Abst., Seism. Soc. Jpn., 1, 177, 1992 (in Japanese).

Ohmi, S. and K. Obara, Deep low frequency earthquakes preceded the 2000 Tottori-ken Seibu Earthquake, Abst., 2001 Jpn. Earth Planet. Sci. Joint Meeting, S3-004, 2001 (in Japanese with English abstract).

Ohtake, M., Ten years since the occurrence of the Matsushiro earthquake 
swarm, Kagaku, 46, 306-313, 1976 (in Japanese).

Oike, K., On a list of hypocenters compiled by the Tottori Microearthquake Observatory, Zisin (J. Seismol. Soc. Jpn.), 28, 331-346, 1975 (in Japanese with English abstract).

Okada, Y. and E. Yamamoto, A model for the 1989 seismo-volcanic activity off Ito, Central Japan, derived from crustal movement data, J. Phys. Earth, 39, 177-195, 1991.

Ooida, T., F. Yamazaki, I. Fujii, and H. Aoki, Aftershock activity of the 1984 Western Nagano Prefecture Earthquake, central Japan, and its relation to earthquake swarms, J. Phys. Earth, 37, 401-416, 1989.

Research Group for Active Faults of Japan, Active Faults in Japan (revised edition), University of Tokyo Press, 437 pp., 1991 (in Japanese).

Sakai, S., T. Yamada, S. Ide, M. Mochizuki, H. Shiobara, T. Urabe, N. Hirata, M. Shinohara, T. Kanazawa, A. Nishizawa, G. Fujie, and H. Mikada, Magma migration from the point of view of seismic activity in the volcanism of Miyake-jima Island in 2000, J. Geogr., 110(2), 145-155, 2001 (in Japanese with English abstract).

Scholz, C. H., The frequency-magnitude relation of microfracturing in rock and its relation to earthquakes, Bull. Seismol. Soc. Am., 58, 399-415, 1968.

Sekiguchi, H. and T. Iwata, Near-source ground motions controlled by source process in the case of the 2000 Tottoriken-Seibu earthquake, Program. Abst., Seism. Soc. Jpn., A73, 2001 (in Japanese).

Shibutani, T. and K. Oike, On features of spatial and temporal variation of seismicity before and after moderate earthquakes, J. Phys. Earth, 37, 201-224, 1989.

Shibutani, T., R. Nishida, S. Nakao, F. Takeuchi, N. Koizumi, and I. Shiozaki, On the earthquake swarm that occurred in the western part of Tottori prefecture in 1989 and 1990, Program. Abst., Seism. Soc. Jpn., 1, 18, 1991 (in Japanese)

Shibutani, T., S. Nakao, R. Nishida, K. Tadokoro, T. Noguchi, K. Miura, N. Hirano, K. Matsumura, and H. Horikawa, Earthquake swarm containing the main event (M5.2) on 4 Sep. '97 that again occurred in western Tottori after the '89 and ' 90 swarm, Abst., 1998 Jpn. Earth Planet. Sci. Join Meeting, 305, 1998 (in Japanese).

Smith, E. G. C. and C. M. M. Oppenheimer, The Edgecumbe earthquake sequence: 1987 February 21 to March 18, New Zealand Journal of Geology and Geophysics, 32, 31-42, 1989.

Suyehiro, S., Difference between aftershocks and foreshocks in the relationship of magnitude to frequency of occurrence for the great Chilean earthquake in 1960, Bull. Seismol. Soc. Am., 56, 185-200, 1966.

Takeuchi, F., T. Tsukuda, R. Nishida, S. Nakao, T. Shibutani, K. Watanabe, K. Nishigami, and K. Oike, Earthquake swarm occurred near the Daisen Volcano in 1985, Annu. Disas. Prev. Res. Inst., Kyoto Univ., 29B-1, 39 47, 1986 (in Japanese with English abstract).

Tsukuda, T., S. Nakao, and R. Nishida, Aftershock distribution of the earthquake (31 October, 1983, M6.2) in the central part of Tottori Prefecture, Program. Abst., Seism. Soc. Jpn., 1, 107, 1984 (in Japanese).

Umeda, Y., M. Hirata, K. Yoshii, S. Ohmi, and K. Ito, The preliminary rupture of 2000 Tottori-ken Seibu Earthquake, Abst., 2001 Jpn. Earth Planet. Sci. Joint Meeting, S3-P001, 2001 (in Japanese with English abstract).

Utsu, T., A method for determining the value of " $\mathrm{b}$ " in a formula $\log n=a-$ $b \mathrm{M}$ showing the magnitude-frequency relation for earthquakes, Geophys. Bull. Hokkaido Univ., 13, 99-103, 1965 (in Japanese).

Utsu, T., Space-time pattern of large earthquakes occurring off the Pacific coast of the Japanese Islands, J. Phys. Earth, 22, 325-342, 1974.

Wessel, P. and W. H. F. Smith, Free software helps map and display data, EOS Trans. Am. Geophys. Union, 72, 441, 1991.

Westerhaus, M., M. Wyss, R. Yilmaz, and J. Zschau, Correlating variations of $b$ values and crustal deformations during the 1990s may have pinpointed the rupture initiation of the $M_{w}=7.4$ Izmit earthquake of 1999 August 17, Geophys. J. Int., 148, 139-152, 2002.

Wiemer, S. and M. Wyss, Mapping the frequency-magnitude distribution in asperities: an improved technique to calculate recurrence time?, $J$. Geophys. Res, 102, 15115-15128, 1997.

Wyss, M., Towards a physical understanding of the earthquake frequency distribution, Geophys. J. R. astr. Soc., 31, 341-359, 1973.

T. Shibutani (e-mail: shibutan@rcep.dpri.kyoto-u.ac.jp), S. Nakao, R. Nishida, F. Takeuchi, K. Watanabe, and Y. Umeda 